\title{
A Comprehensive Study on Private Universities in Bangladesh: Service Rules and Job Satisfaction
}

\author{
Mohammad Golam Moula, Md. Obaidullah, Kamrunnahar
}

\begin{abstract}
Service rules make it easier for an institution to pursue higher education. In order to ensure quality education, it is essential that educational institutions have service rules. The service rules of university employment are considered to be conducive to the higher education system. On this article discusses the importance of service rules. Each step of the service rules is shown with the help of diagrams and each of the steps is discussed separately. To certify higher education has played a noteworthy part in Bangladesh. The rules clearly specify the rights and duties of workers and employers where every institution must have its own service rules regulating any employment but cannot be contradictory to any establishment of the labor laws. Job satisfaction is considered as a vital determinant of job activities. Some of the universities are providing quality education but rests of them are not quality concerned, most of them are depending on Daily basis teachers, poor infrastructures, without service rules etc. The trial was taken on a random basis from four private universities in Bangladesh. The sample size is forty-five. The result of this study shows that about job satisfaction level of employees in the selected universities. In the end, based on results, researchers have offered some suggestions that can be taken into thought in strategy level.
\end{abstract}

Keywords: Service Rules, Job Satisfaction, Survey Data, Quality standard, Higher Education,

\section{INTRODUCTION}

A strong affiliation between employee satisfaction and customer satisfaction with the service quality is considered very important for executive strategy that attentions on a comprehensive approach to manage service quality. Service rules and getting job satisfaction is the vital part to preserve quality education in private University. It has been observed that, without satisfaction of the employees, it's quite difficult to run university standard ensuring the job security is essential part. UGC is working on its plan to frame a mandatory service rules for the private university teachers and staff. Many of the existing private universities do not give their academic staff any benefit. On termination of their job, they get nothing. Many teachers and staffs want to leave

Manuscript received on June 19, 2021.

Revised Manuscript received on June 29, 2021.

Manuscript published on June 30, 2021.

* Correspondence Author

Mohammad Golam Moula*, Assistant Registrar, Sheikh Fazilatunnesa Mujib University, Jamalpur, Bangladesh

Md. Obaidullah, Accounts Officer, Sheikh Fazilatunnesa Mujib University, Jamalpur, Bangladesh

Kamrunnahar, Assistant Teacher, Business and Management, Bangabandhu Ideal School and College Jamalpur, Bangladesh

(C) The Authors. Published by Blue Eyes Intelligence Engineering and Sciences Publication (BEIESP). This is an open access article under the CC BY-NC-ND license (http://creativecommons.org/licenses/by-nc-nd/4.0/) the job because of the lack of security. There are some private universities where staffs and teachers get such amount of remuneration by which it's very tough to run the family in minimum standard. There is no option to earn extra money by the universities employees and teachers. For protecting the genuine interest of a private university employees and service rules is mandatory for them. Researcher believes that if the employees are happy whatever the services they provided to the students it will be effective.

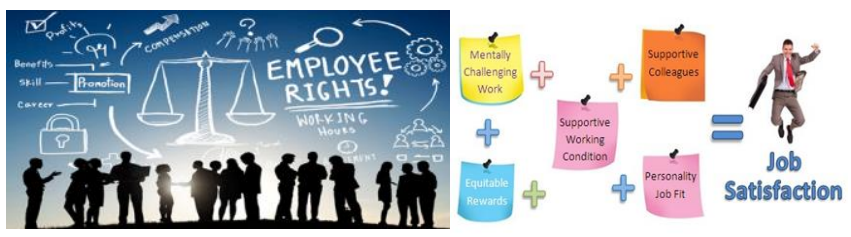

Figure 1: Employee rights and Job satisfaction

Service Rules: What types of agreements will be acceptable between employers and employees? Underneath what conditions can the relationship be terminated? What are the requirements for providing advance notice? What are the obligations of the employer regarding severance or termination payments? These are important questions for policy-makers in addressing the trade-offs between employment market give and the economic security of employed hands. Service Rules indicates that the Company's/Organization Behavior, Restraint \& Appeal Rules and other Service Rules bordered and executed by the Company/Organization in relation to terms and conditions of service of its Employees. Employment defense - the set of service rules leading appointment and dismissing employees - is a key article of any country's employment arcade. On the other hand, it means the Conduct, Discipline and Appeal rules in case of Management employees and the applicable Standing Orders in case of employees other than Management employees. It is as framed by the Management which are applicable to all employees, may be amended or modified from time to time by the management.

Job Satisfaction: For employers, job satisfaction for an employee is an imperative aspect to get the best out of them. A satisfied employee always gives more to the company, helps controller erosion \& helps the company grow. Employers need to guarantee a good job description to attract employees and constantly give opportunities to individuals to learn and grow.

Published By: Blue Eyes Intelligence Engineering \& Sciences Publication

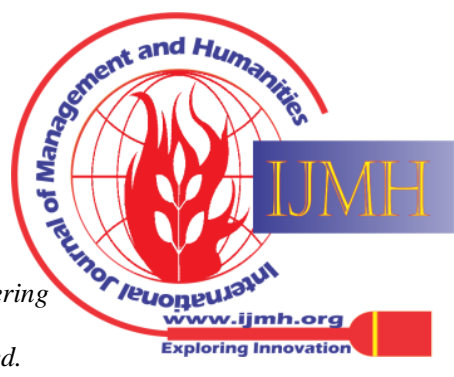


For employees, Job satisfaction from an employee viewpoint is to earn a good gross salary, have job constancy, have a steady career growth, get rewards \& respect and constantly have new prospects. Job satisfaction is defined as the scope to which an employee touches self-encouraged, satisfied \& pleased with his/her job. Job satisfaction ensues when an employee touches him or she is having job constancy, career progress and a relaxed work life balance. This indicates that the employee is having satisfaction at job as the work meets the potentials of the specific.

\section{LITERATURE REVIEW}

Service rules and Job satisfaction is considered as a vital parameters of job behavior. A few number of researchers worked on service rules of private university in Bangladesh as well as the job satisfaction of private university in Bangladesh. Nimalathasan, B., \& Ather, S. M. (2010) has discussed quality of work life (QoWL) and Job satisfaction (JS) in their research paper [1]. They have focused a case study of academic professionals of private Universities in Bangladesh. Sultan, P., \& TaRaFDER, T. (2007) has investigated critical factors in service quality measurement for private universities. In their research they have shown a competitive case study on Bangladeshi private universities [2]. Hossain, M. Y., \& Hossain, M. N. (2016) have explained job satisfaction of private university teachers in Bangledesh graphical survey is shown in this paper to understand the job satisfaction level with different questionnaires and public respondents. Davis, A. J. (1996) has researched on a re-analysis of the occupational stress indicator. Work \& Stress [4]. In their research they have mainly focused on two parameters such as work and stress. Sarker, M. N. I., Sultana, A., \& Prodhan, A. S. (2017) have focused job satisfaction of employees of public and private organizations in Bangladesh [5]. They have shown various survey reports using various public respondents.

\section{OBJECTIVES OF THE RESEARCH}

* To identify almost real situation of service rules for private Universities in Bangladesh.

* To study the job satisfaction level of employees of selected universities.

\section{METHODOLOGY OF THE RESEARCH}

The main cause of data used was a ground level survey directed by the researcher from the selected universities in Bangladesh. A structured questionnaire was used in the survey. The questionnaire included 10 questions on various aspects of services rules and regarding job satisfaction. Structured questions were used where sample frame is selected four Universities- Sheikh Fazilatunnesa Mujib University, Sonargaon University, Uttara University, Pundra University of science and technology Sample Size is 45, Sample Procedure: Simple Random Sampling, Population Size:180 [3]. The research work is done using 254 data set and a

Dynamic Substances of Services Rules for Employees and minimum standard for success Job satisfaction should be surveyed by the Private Universities:

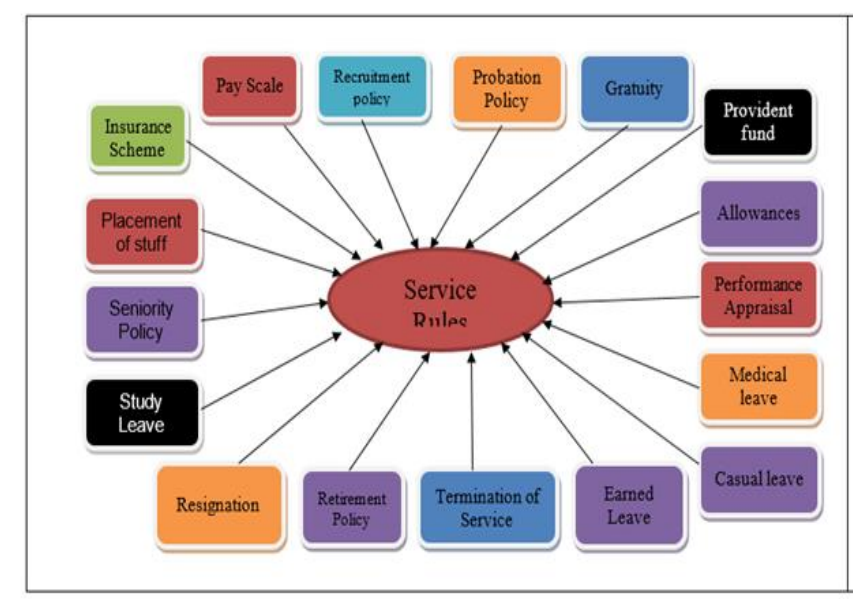

Figure 2: Vital Contents of Service Rules

\section{Employs Recruitment:}

Recruitment refers to the process of identifying, attracting, and interviewing, selecting, appointment and onboarding organizations. In other words, it includes everything from the identification of a recruitment need to satisfying it. Dependent on the scope of an institute, enrolment is the accountability of a variety of employees. Larger administrations may have complete teams of recruiters, while others only a particular recruiter. In small suits, the appointment employees may be responsible for recruiting.

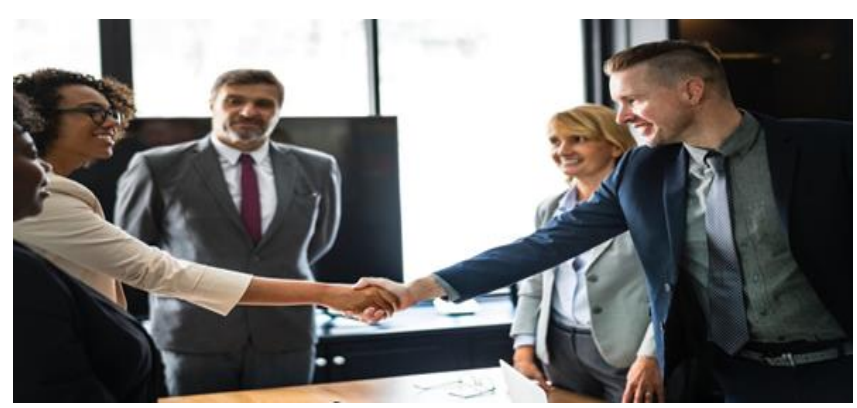

Figure 3: Employs Recruitment

\section{Pay Scales:}

A pay scale also identified as a salary erection which is a classification that defines how much an employee is to be compensated as a wage or salary, founded on one or more influences such as the employee's equal, rampant or status within the employer's association, the dimension of time that the employee has been in employment, and the effort of the precise work achieved. All regularly appointed teaching faculty and staffs are governed by the pay scales approved by the management from time to time on the basis of UGC scale of pay

\section{Probation Policy:}

Probation can be broadly defined as a trial period for newly recruited workers. Probation periods commonly last for three months, six months, or a year.

Published By:

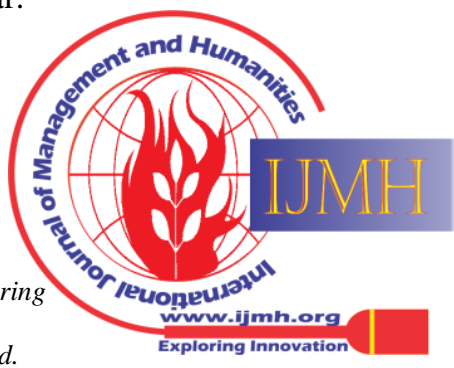


The appointment to any post in the university is temporary for a period of one year. After assessing the performance during the year and if found to be satisfactory, the services will be continued for another year

\section{Gratuity:}

All the members of staff (Teaching \& Non-Teaching) who have put in a minimum of 5 years continuous service (Excluding leave on loss of pay) in the University shall be paid service gratuity at the rate of $1 / 2$ month's salary (Pay + DA) for every one year service for the total completed years of service.

\section{Insurance Scheme:}

All members of staff (Teaching \& Non-Teaching) are covered by a group personal accident cum hospitalization policy. The premium is paid by the management during January each year. The benefits of the scheme are, A sum of TK.1,00,000/- (Tk one lakh only) per person for death and permanent total disablement, only if arising out of accident. Coverage of medical expense to the tune of Tk .50,000/- (Tk fifty thousand only) per person for hospitalization / medical expenses incurred as inpatient for grievous injuries arising out of accident only.

All the members of staff (Teaching \& Non-Teaching) other than those who joined the University after completing the age of 58 years are enrolled under the EPF scheme from the date of joining in service.

\section{Allowances:}

Allowances such as Dearness Allowance (DA), House Rent Allowance (HRA) and other allowances if any shall be as fixed by the management from time to time for all regular employees

\section{Performance Appraisal:}

The Management of the University reviews the performance of faculty members and staffs every year and based on this, annual increment, career advancement, etc. will be given to the faculty. The following are the important provisions.

\section{Placement of staff:}

A staff member selected for appointment is ordinarily attached to the Department to which he/she was selected. However, the Management/competent authority has the right to redeploy the staff member in any other Department in the interest of the University and depending upon the need and exigency

\section{Seniority:}

If two or more persons are selected for appointment at the same time to a particular category of post, the selection committee shall fix the order of seniority among them according to the merit of the candidate selected and in the absence of such merit list the seniority shall be fixed as per the date (and time) of joining of the staff member for duty in the University.

\section{Study Leave:}

A faculty member may be granted a maximum of 24 months of study leave without salary for pursuing higher studies, with a duly executed bond to serve the University on

\section{Employee Provident Fund Scheme:}

return for 3 years. Otherwise he/she shall resign from current position to proceed for higher studies without a bond.

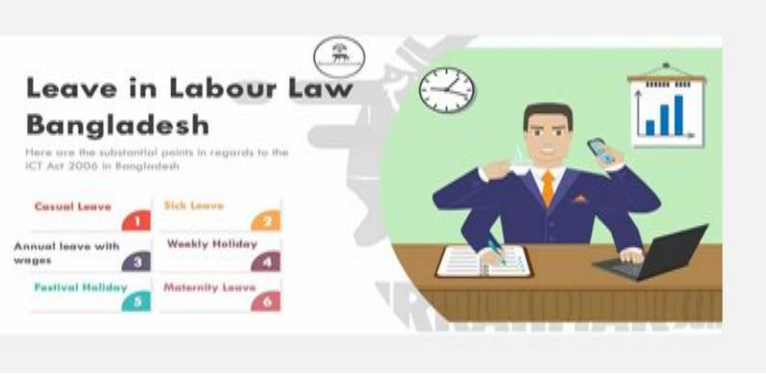

Figure 4: Leave in labour Law Bangladesh

\section{Casual Leave (CL):}

Casual Leave or CL is granted to an eligible employee if they cannot report to work due to an unforeseen situation all staff members are eligible for 12 days of casual leave per calendar year.

\section{Earned Leave (EL):}

All members of staff (Teaching \& Non-Teaching) are permitted to earn leave at the rate of $1 / 22$ of duty, subject to a maximum of 24 days for the first 2 years of service. After completion of 2 years' service all staff members are permitted to earn leave more than 24 on special consideration

\section{Maternity Leave:}

Maternity leave shall be granted for a maximum period of 25 weeks. Such sanction is restricted to two confinements only. All the members of staff (Teaching and Non-Teaching) who have completed two years of service only are eligible to avail this leave. During probationary period no Maternity leave is available and it shall be only on loss of pay.

\section{Medical Leave:}

A medical leave of absence is a much longer commitment due to a serious health condition or family medical emergency. All staff members (teaching and non-teaching) who complete two years of service are eligible for sanction of 10 days of Medical leave for each completed years of service. They are permitted to accumulate this leave up to a maximum of 60 days. Medical leave can be availed only in the case of illness requiring hospitalization.

\section{Termination of service:}

The University can relieve any staff member by giving him / her three months' notice or three months' salary in lieu of the notice, at any time in a semester

\section{Retirement:}

Retirement refers to the time of life when one chooses to permanently leave the workforce behind normally the age of superannuation of a faculty and staffs are 60 years. However, reappointment up to the age of 70 years on contract can be considered depending on the need.

\section{Resignation:}

If a staff member (Teaching or Non-Teaching) intends to resign from this university, he / she shall give either 3 months'

Published By:
Blue Eyes Intelligence Engineering

\& Sciences Publication

(C) Copyright: All rights reserved.

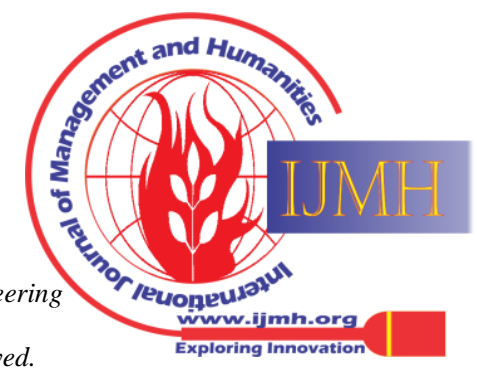




\section{A Comprehensive Study on Private Universities in Bangladesh: Service Rules and Job Satisfaction}

notice in advance or pay three months' salary to the university in lieu thereof. The Three months' notice period shall be co-terminus with the semester only.

\section{Findings}

1) According to the statement of effective service rules convey the job satisfaction of employees, the survey report shows $74 \%$ respondents said yes and $26 \%$ respondents said no.

\section{Effective service rules convey job satisfaction of employees}

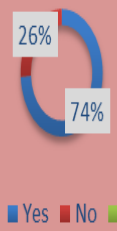

Figure 5: Effective service rules convey job satisfaction of employees

2) According to the survey report, on the question of scope of effective service rules in private universities, $9 \%$ respondents strongly disagree, $15 \%$ respondents disagree, $27 \%$ respondents said neutral, 35\% respondents said agree and $14 \%$ respondents said strongly agree.

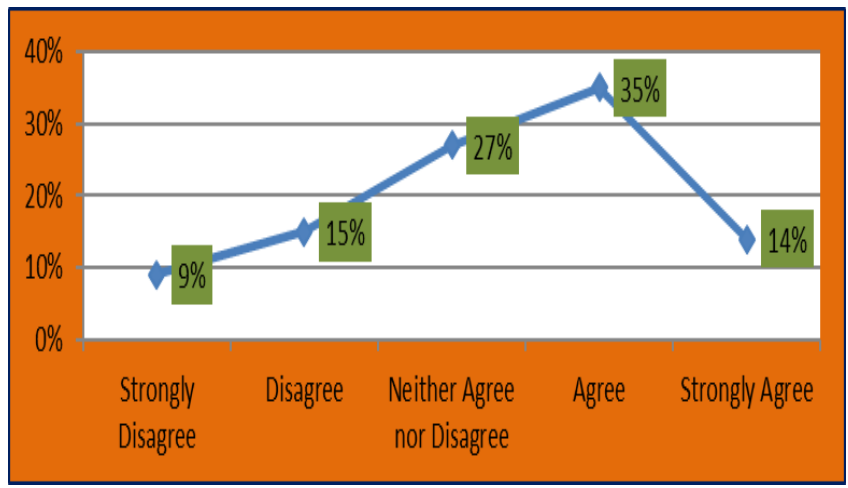

Figure 6: Scope of effective service rules in private universities

3) The respondents of about $61 \%$ said the services rules are not active and $39 \%$ said the service rules are active. A small number of Institutes have service rules but not properly followed.

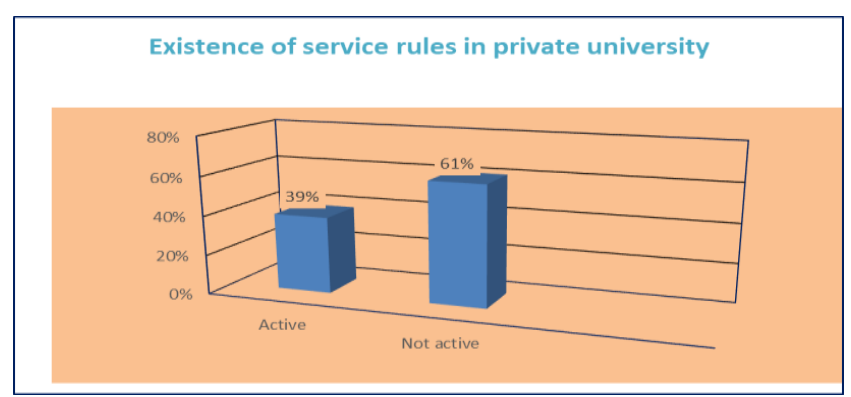

Figure 7: Existence of service rules in private university

4) According to the question of job dissatisfaction is a barrier to provide quality education, the survey report shows $8 \%$ respondents strongly disagree, $10 \%$ respondents disagree, $27 \%$ respondents said neutral, $43 \%$ respondents said agree and $12 \%$ respondents said strongly agree.

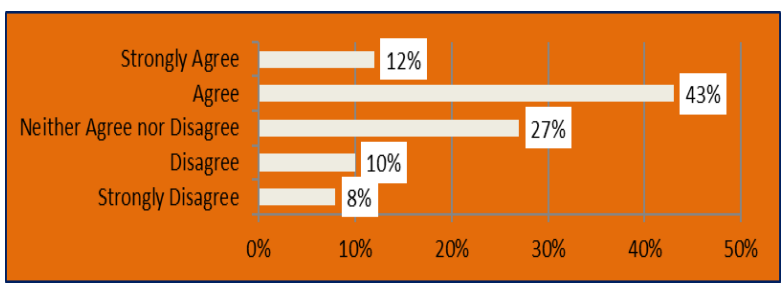

Figure 8: Barrier to provide quality education

5) Service rule is mandatory for protecting the genuine interest of private universities employees. According to this statement, $91 \%$ said yes and $9 \%$ said no.

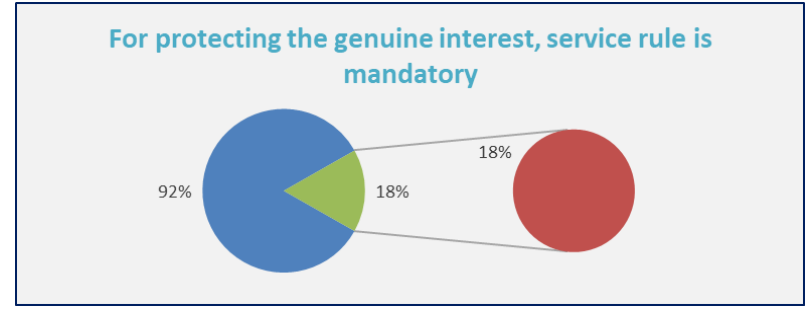

Figure 9: genuine interest of private universities employees

6) Why service rules are essential? On this question, survey report shows $45 \%$ said protecting the job, $46 \%$ said maintain the rights of the employees and $9 \%$ said avoid the nepotism.

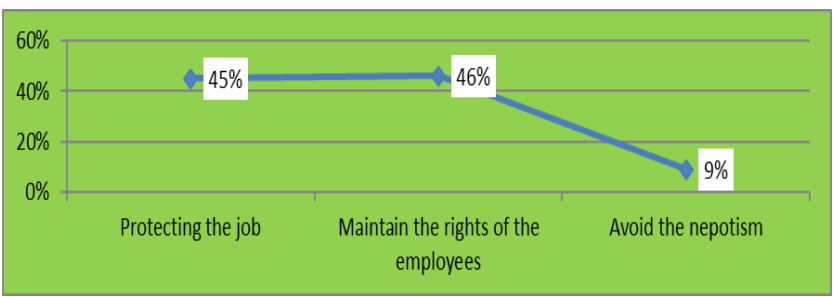

Figure 10: service rules are essential

7) According to the statement of Private Universities should announce uniform service rules for employees, the survey shows $84 \%$ respondents said yes and $16 \%$ respondents said no.

Need uniform service rules for employees

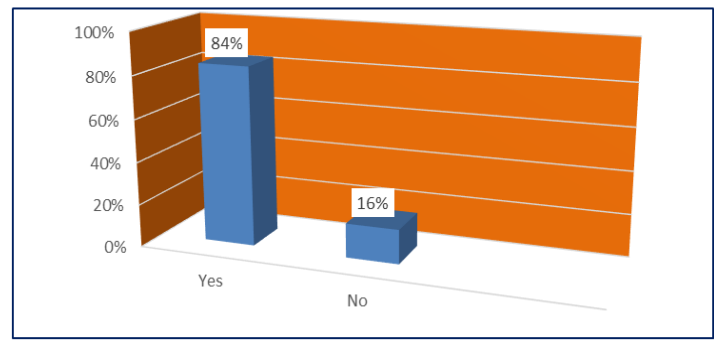

Figure 11: Statement of Private Universities should announce uniform service rules for employees

Published By:

Blue Eyes Intelligence Engineering

\& Sciences Publication

(C) Copyright: All rights reserved.

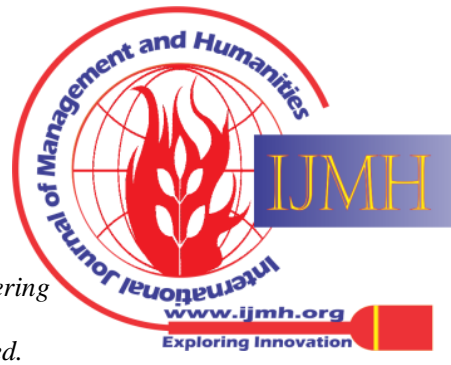



and ability. On this statement, survey report shows 9\% respondents strongly disagree, $20 \%$ respondents disagree, $22 \%$ respondents said neutral, $31 \%$ respondents said agree and 18 respondents said strongly agree.

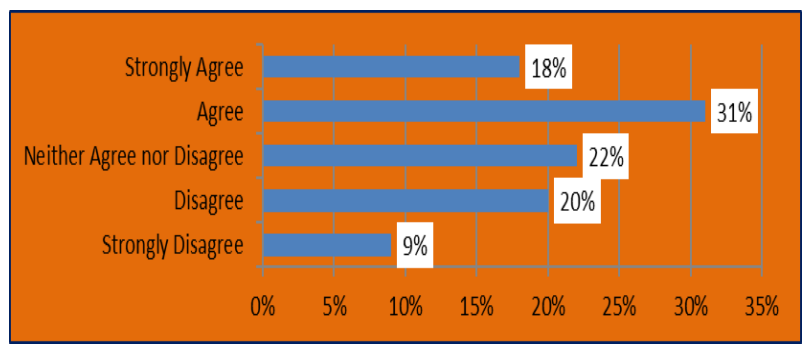

Figure 12: Pleased employees provide the best of their competency and ability

9) How pleased you are with your job and service rules? The survey report shows 19\% respondents said best, 20\% said better, $22 \%$ said good and $39 \%$ said not good according to this question.

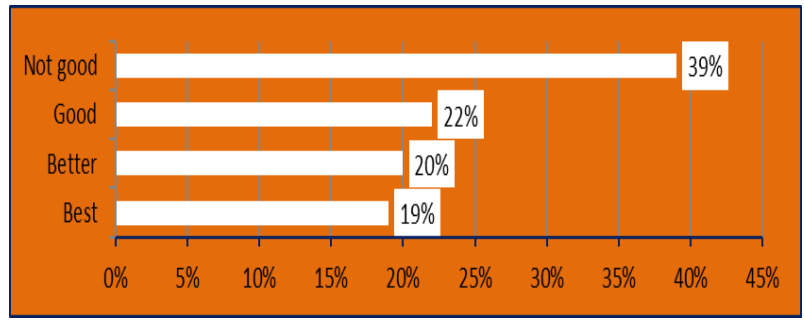

Figure 13: pleased you are with your job and service rules

10) According to the survey report, on the statement of Government should set up service rules for private universities, 94\% respondents said yes and 6\%respondents said no.

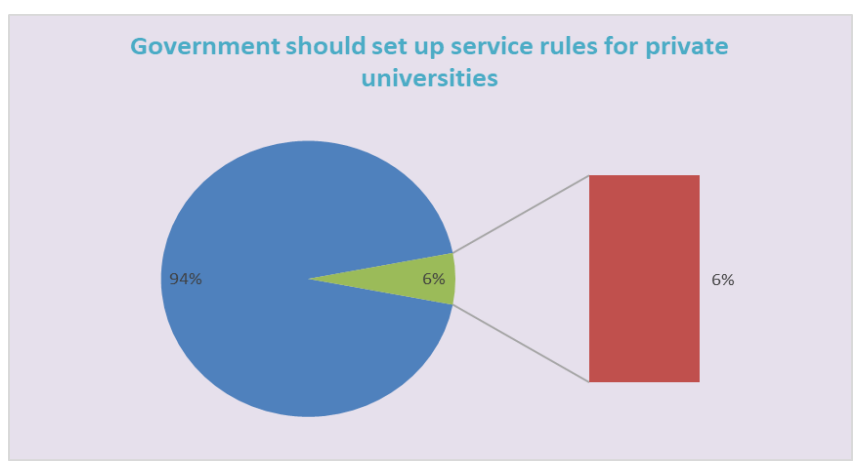

Figure 14: Government should set up service rules for
private universities

\section{RECOMMENDATION}

1) Universities should effort how to content the employees and find out the problem which is noticeable and alleviate as soon as possible.

2) Service rules ought to be employees friendly so that all the employees feel secure to their job. It's mandatory to get better services from them.

3) It has been evidenced that operative service rules bring the job happiness for the employees. Service rules is the rules and every private University has service rules to make sure the
8) Pleased employees provide the best of their competency regulation of job which preserve the employee's rights. So

employees satisfaction.

4) The main purpose of the private University is to provide quality education to the students where all the staffs, management and faculty fascination and dedication are mandatory. So, effective and efficient policy is needed so that they feel satisfied.

5) In a service rules, there are numbers of elements. University should focus employee's friendly policy so that best output achieved by them

6) Every private University should follow uniform service policy so that no one can deprive from their rights.

7) There is an effective scope of service policy in private universities. So, higher and concerned authority should take necessary initiatives.

8) For protecting the general interest of private University teachers, staffs, and employee's service rules is mandatory.

9) Service rules just not only save the rights of employees but also make the University proud. So service rules are inevitable.

10) Government should take necessary initiatives for private universities regarding service rules. If government found any effective service rules in private universities, should identified them and take legal action.

\section{CONCLUSION}

As a final point, researchers have been able to show that if service rules are applied in a university, then the track to employee satisfaction is easier as the institution ensures higher education. The way, in which a realistic diagram has been highlighted in the article with the help of data collection and illustrations, so it is very easy to assume that the detailed discussion in the article will make it easier for the organization to improve if it can be implemented. The amount of payment for basic salary, house rent, health allowance, delivery, etc. can be secure after conversation by the significant investors counting employee's representatives and university specialists. By this way to continue excellence education and make employees pleasure is possible.

\section{REFERENCES}

1. Nimalathasan, B., \& Ather, S. M. (2010). Quality of Work life (QoWL) and Job Satisfaction (JS): A study of academic professionals of private Universities in Bangladesh. In Annual Research Conference ARC)-2010, University of Jaffna, Jaffna, Sri Lanka.

2. Sultan, P., \& TaRaFDER, T. (2007). Critical factors in service quality measurement for private universities: the case of Bangladesh. Ritsumeikan Journal of Asia Pacific Studies, 22(1), 75-98.

3. Hossain, M. Y., \& Hossain, M. N. (2016). Job satisfaction of private university teachers in Bangledesh. European Business and Management, 8(13), 106-112.

4. Davis, A. J. (1996). A re-analysis of the occupational stress indicator Work \& Stress, 10(2), 174-182.

5. Sarker, M. N. I., Sultana, A., \& Prodhan, A. S. (2017). Job satisfaction of employees of public and private organizations in Bangladesh. J Polit Sci Public Int Aff, 1(1), 1-8.

6. Service rules for private university teachers. retrieved fromhttps://m.theindependentbd.com/arcprint/details/9498 0/2017-05-18

7. Ellickson, M. C., \& Logsdon, K. (2002). Determinants of job satisfaction of municipal government employees. Public Personnel Management, 31(3), 343-358

Published By:

Blue Eyes Intelligence Engineering \& Sciences Publication

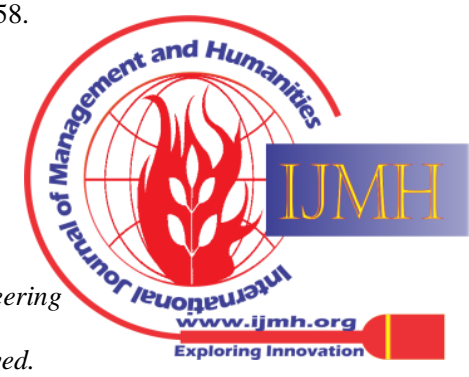


8. Altimus Jr, C. A., \& Tersine, R. J. (1973). Chronological age and job satisfaction: The young blue collar worker. Academy of Management Journal, 16(1), 53-66.

9. Employee Rights \& Labour Law in Bangladesh - All you need to know about Employment Law retrieved from https://tahmidurrahman.com/employee-rights-labour-law-i n-bangladesh/

10. Kader, A., \& Salam, A. (2019). PRIVATE UNIVERSITIES OF BANGLADESH: A STUDY ON SERVICE QUALITY, CUSTOMERS'PERCEPTIONS AND SATISFACTION. International Review of Business and Economics, 3(1), 109-125.

11. Teachers' Job Security at Private Universities: A Reality Check retrieved from

https://www.daily-sun.com/arcprint/details/305003/Teach ers\%E2\%80\%99-Job-Security-at-Private-Universities:-AReality-Check-/2018-04-27

12. Employee Rights \& Labour Law in Bangladesh - All you need to know about Employment Law retrieved from https://tahmidurrahman.com/employee-rights-labour-law-i n-bangladesh/

13. https://www.google.com/url?sa=i\&url=https $\% 3 \mathrm{~A} \% 2 \mathrm{~F}$ \%2Fblog.ipleaders.in\%

14. https://www.google.com/url?sa=i\&url=https\%3A\%2F \%2Frecruitingtimes.org\%2Fnews\%2F25971\%2Fbritish-w Orkers-snap-up-almost-all-uk-jobs-since-brexit-vote-as-e Mploymentcontinues\%2F\&psig=AOvVaw0uTciQdrJQiqa zbCKpwtrN\&ust=1619423234909000\&source=images\&c $\mathrm{d}=\mathrm{v} \quad$ fe\&ved=0CAIQjRxqFwoTCJD1uOnzmPACFQAAAAAd AAAAABAk

\section{AUTHORS PROFILE}

Mohammad Golam Moula, B. Com (Hons) M. Com (Management) Assistant Registrar, Sheikh Fazilatunnesa

Mujib University, Jabalpur, Bangladesh.
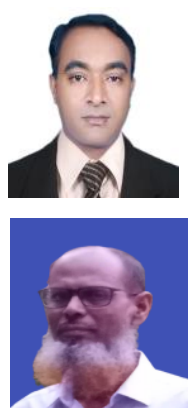

Md. Obaidullah, Diploma in Banking, Accounts Officer Sheikh Fazilatunnesa Mujib University Jamalpur, Bangladesh

Former Executive Officer, Sonali Bank Limited, Bangladesh

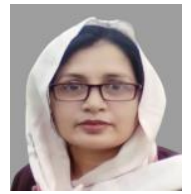

Kamrunnahar, Assistant Teacher, Business and Management, Bangabandhu Ideal School and College, Jamalpur, Bangladesh

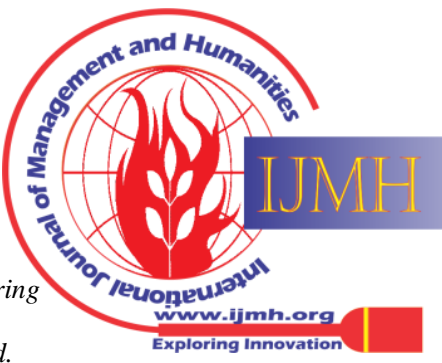

